\title{
Missio Dei as the Main Project: Project Management Model for Mission of God
}

\author{
Jonas Sello Thinane \\ Hebrew Senior Departmental Administrator \\ Faculty of Humanities \\ University of the Free State (UFS), South Africa \\ E-mail: jsthinane@gmail.com \\ https://orcid.org/0000-0002-8522-8519 \\ DOI: https://doi.org/10.46222/pharosjot.102.221
}

\begin{abstract}
The emergence of the concept of Missio Dei (Mission of God) from the perspective of the International Missionary Council (IMC) arguably demonstrated that the role of the Triune God in his own mission was undeservedly marginalized for decades, if not centuries preceding 1952. Over the past decades there has been a sustained research activity conceptualizing Missio Dei, and at the same time renewing missiological interest in other Christian missions. However, to the author's awareness, there has been very little or no effort to introduce or use known project models that can be utilized to show coherence or collaboration of missions towards the project of fulfilling the objective of Missio Dei. Through a desk-top literature review, this paper proposes the use of a project management model to properly conceptualize the location of Missio Dei as a main project that includes other network of missions as sub-projects within its framework. The Triune God is here identified as Project managers while human participants are seen as project stakeholders. Christian missions include Missio Christos, Missio Spiritus, Missio Hominum and Missio Ecclesiae as sub-projects. The proposed model will demonstrate the coordination and collaboration of missions in the broader context of Missio Dei and further assist with a proper understanding of roles that each mission is, or should play, in achieving the objective of Missio Dei. While efforts are being made here to propose a project management model for Missio Dei, further research is needed to determine whether this proposal will yield an in-depth understanding of Missio Dei as a missiological paradigm in conjunction with the role of other missions.
\end{abstract}

Keywords: Missio Dei, Missio Christos, Missio Spiritus, Missio Hominum, Project Management.

\section{Introduction}

The work in this paper is primarily motivated by the reality that the author of this paper while doing undergraduate theological studies at the Theology faculty in the University of the Free State, despite the missiological articulateness of the then missiology teacher, Professor Pieter (P) Verster, to introduce the concept of Missio Dei and other related paradigms, comprehending this concept remained problematic since there was no standardized model that incorporated these paradigms in a manner that showed coherence and unified purpose of fulfilling the goal of Missio Dei. This problem persisted beyond the higher qualifications of the author. The main idea in this paper is to suggest the use of a project management model to solve this problem. However, while the proposed model may seem overwhelming and too simplistic at the same time, it will aid or guide the process of organizing these missiological paradigms into a memorable framework. Further, while efforts are being made here to propose a project management model for Missio Dei, further research is needed to determine whether this proposal leads to a deeper understanding of Missio Dei as a missiological paradigm. 
Further research is expected to potentially develop new types of project management models that address other problems related to missiological paradigms.

The emergence of the concept of Missio Dei was from the perspective of the International Missionary Council (IMC) meeting that took place in a small village of Germany called Willingen in 1952. What emerged out of this gathering was the realization or more of a "wakeup call" indicating that for decades if not centuries, Christian missions have been deeply misplaced and misunderstood, in fact so much so, that they undeservedly enjoyed more attention that Missio Dei. From the point of Willingen the biggest task for the church and missiologist in particular has been to correctly place missions within the context of Missio Dei. Inherently, this transition brought fresh insightful perspectives on the correct role that Christian world missions ought to play within the broader framework of the Missio Dei. This paper will make use of a project management model to seek to correctly conceptualize the place of Missio Dei as the main project encompassing other network of missions as sub-projects within its framework.

The author is of the view that it is from the framework of Missio Dei that other Christian mission activities such as Missio Christos, Missio Spiritus, Missio Hominum and Missio Ecclesiae receive their identities and are in essence organized towards accomplishing the goal of Missio Dei. It suggests using a project management model to properly order these missiological paradigms. This correct order of missions in relation to Missio Dei will theorize mission collaboration and further provide a balanced account of divine and human participation in the project of Missio Dei. This research is a first step towards a more profound understanding of the holistic role played by other modules within the broader continuum of Missio Dei.

This paper presents a proposal that attempts to use the project management model to unite Christian missions under Missio Dei. First, it presents the concept of project management and its application to Missio Dei. Second, it discusses the background or the development of Missio Dei as a missiological paradigm. Third, it focuses on a network of Christian missions outlining Missio Christos as Project A, Missio Spiritus as Project B, Missio Hominum as Project C, and Missio Ecclesiae as Project D, as sub-projects that specifically serve the purpose of achieving the goal of Missio Dei.

\section{A Project Management Model}

Project management can be defined in many different ways depending on organizational outlook. According to Project Management Institute $\{$ PMI\}(2017), practices of project management have been in use for over hundreds of years but only by the mid-20 $20^{\text {th }}$ century did managers of projects seek recognition that would ultimately make project management a profession (PMI, 2017:1). Despite its association with business community, project management is the easiest model to incorporate in any organizational setting. In this paper, this model will be utilized to provide a framework within which Missio Dei relates to and manifest in other Christian missions. Consistent with this idea, Matthey (2003) says: "Missio Dei theology has clearly broadened the horizon and fostered a wide understanding of and approach to mission that are of lasting importance" (Matthey, 2003:580). In fact, Suess (2003) argued that the divine plan as comprehended within the framework of Missio Dei can be correctly interpreted as God's project which will subsequently be continued in other projects such as such as Missio Christos, Missio Spiritus etc. (Suess, 2003:555). In its simplicity, this model will assist in placing or outlining specific roles for Christian missions within the broader context and mandate of Missio Dei. Here, Christian missions are viewed as unique subprojects to be managed or facilitated precisely in accordance with the mandate of Missio Dei. Within the context of Missio Dei, where multi-project exist concurrently or run simultaneously and co-headed by union of the Father and Son and Holy Ghost in one Godhead (Trinity), it may be very helpful to introduce a project management model to assist the process of drawing some sort of a breakdown structure. This model will further help the process of bringing all 
these missions into a uniform approach and identify set of roles that each mission ought to play in fulfilling or meeting the strategic goal of Missio Dei. This means Christian missions such as Missio Christos, Missio Spiritus, Missio Hominum and Missio Ecclesiae here are used or viewed as instrumental projects by which Missio Dei seeks to accomplish its strategic objective.

Huda (2016) defined "project" as a temporary course which consist of a defined beginning and end in time wherein a specific set of operations are designated to accomplish a particular goal (Huda, 2016:1). Koskela and Howell (2002) on the other hand, firstly described "project" as an endeavor or course that conceptualizes transformation of inputs or service into outputs, while management involves planning and implementation (Koskela \& Howell, 2002:2). In regard to Missio Dei, arguably the project start time could refer to the time immediately after the fall of mankind as recorded in the book of Genesis 3:1-24. This narrative describes humankind's transition from a state of innocence to the state of disobedience. In essence, this signifies the natural point in time from which the omniscient Triune God could have begun His salvific plans, and is thus the starting point of Missio Dei.

According to Turner and Muller (2003), a project is characterised by diverse work activities which are carried over a period of time towards achieving one or more defined objectives (Turner and Muller, 2003:1-5). Consistent with this approach, Sundermeier (2003) argues that another dimension of mission is regulated by time to ensure coherence across the many stages of mission. He points to Jesus' proclamation of the kingdom of God and the final epiphany of such kingdom as mission time determining factors (Sundermeier, 2003:569). In the light of Missio Dei, diverse work activities will constitute various phases of projects such as Missio Christos, Missio Spiritus, Missio Hominum and Missio Ecclesiae as sub-projects aimed at fulfilling the objective of Missio Dei or Total salvation as the intended output.

In any project, different people with different skills and knowledge are brought together in order to use their skills to achieve the specified goals. It is precisely for this reason that Cheng et al (2005) wrote: "Disparate groups of individuals from different organisations are brought together for short periods to work collaboratively towards project goals" (Cheng et al 2005:25). Turner and Muller (2003), similarly to Cleland and Kerzner (1985), equally defined project management as: "A combination of human and non-human resources pulled together into a temporary organization to achieve a specified purpose" (Turner \& Muller, 2003:3).

Though introducing different types of project management models is not within the scope of this paper, it is important to mention that there are numerous types of project management models suitable for specific projects used by various industries. The inexhaustible list of project management models will include; Waterfall project management model wherein projects are completed in a lined or sequential manner (Van der Merwe 2017:1-2), Agile project management model that is open to changes, revision and collaboration or adaptation (Antlova 2014:929-933), and many other models that are mainly hybrids of waterfall and agile models. For further reading on these other models, one can consult scholars such as (Chin, Spowage \& Yap, 2012; Karaman \& Kurt, 2015; Wells, 2012) and many others. That being the case, since the aim of this paper is merely to introduce or suggest the use of project management models for Missio Dei, no particular model is identified as being suitable enough for Missio Dei at this point. Instead, the general use of project management is used to draw scientific attention to this possibility.

\section{Missio Dei as Main Project}

Through the hands of history, the concept of Missio Dei became important within the field of missiology. Essentially, Missio Dei emphasised the idea of mission to be originally about God and his redemptive acts through the history of humankind. Inherently, Missio Dei is all about 
the divine salvific plan, while other missions, conceived with the help of the divine through the commissions of the Son and Spirit, involve human participation.

Missio Dei as the main project consist mainly of the key management group or the work of divine entities (the Triune God) who is responsible for the project in its entirety. One can call these entities the project board, project principals or project superior managers in collaboration with various groups of people as merely project stakeholders. In Missio Dei, God the Father, God the Son and God the Holy Spirit are equally the superior principals and owners of the Missio Dei project. The Triune God as the project manager alone knows the ultimate goal of Missio Dei and He alone knows best how to achieve it.

The section below will look into the evolution of Missio Dei through the hands of history which subsequently will give birth to sub-projects, namely, Missio Christos, Missio Spiritus, Missio Hominum and Missio Ecclesiae. It is the view of this paper, that Missio Dei supersedes all other projects as it includes members of Trinity with exclusive power and authority over all other missionary projects. In fact, consistent with the argument of this paper, scholars such as Konz (2018) went as far as declaring Missio Dei as an all-encompassing model of mission. The following section shows how the issue of mission has led to heated debates over the decades that eventually made Missio Dei the focus and central to all other missions. The historical emergence of Missio Dei as a paradigm will demonstrate why it is necessary to designate it as the main project within the context of all other missions, and further why it is important to use it as a theological framework for all other missions.

\section{Missio Dei pre-Willingen}

Missio Dei as a missiological paradigm no longer urgently needs clarity of definition, since numerous scholars have fulfilled such an important task. However, it can be broadly described as a Latin theological expression to mean the "Mission of God". That being said, the idea of the Missio Dei has its roots in decades that preceded the well-known International Mission Council of Willingen of 1952. The excellent work of Goheen (2010) traces the period from 1938 to 1952 wherein several assumptions about the role of the church in mission and ideas led to the groundbreaking paradigm of Missio Dei (Goheen, 2010:63-67). Scholars such as Engelsviken (2003) and Kamper (2014) point to the origin of Missio Dei to St Augustine's time. Engelsviken (2003) wrote: "The term Missio Dei has a long history that goes back to Augustine and relates to the doctrine of the Trinity" (Engelsviken, 2003:482) while Kamper (2014) explains that the concept of Missio Dei is attributed to Augustine as one who described mission as God's work wherein the faithful are involved merely as participants (Kamper, 2014:188). To substantiate this view, Buys (2020) cited Schirrmacher (2017) who equally suggested that the concept of Missio Dei was used by St Augustine in the $4^{\text {th }} \mathrm{CE}$ and subsequently by St Thomas Aquinas to explained mission in the light of the sending of God the Son by God the Father, and the sending of God the Holy Spirit by God the Father and the Son (Schirrmacher, 2017:9-10, 82; Buys, 2020:5). However, it is important at this stage to emphasis that even though God the father is portrayed as the sending entity of the Son and ultimately the Holy Spirit, He remains mysteriously present throughout all phases of mission. To explain this in clear terms, Suess (2003) argues that the Triune union and sending narrative holistically points to the eternal presence of God. In this whole sending process, God the Father does not remain behind but instead He is revealed as being the sent Son and the Holy Spirit hence Jesus Christ could make bold statements such as: "whoever has seen me has seen the father" (John 14:9). On this Sarisky (2013) writes: "Jesus' shocking statement is that in his person the rule of God was present” (Sarisky, 2013:260). Suess correctly puts it:

The arrival of logos and pneuma in our very small world, cosmologically speaking, does not make God or parts of God absent elsewhere, but can only be understood as a special manifestation of the one and all-present God under historical and anthropological conditions (Suess, 2003:553). 
According to Engelsviken (2003), the American missiologist, James A. Scherer indicated that the concept of Missio Dei as it relates to the work of Triune God could be found in Martin Luther's thinking even before the $20^{\text {th }}$ century. He wrote: "for Luther, mission is always preeminently the work of the Triune God". This means Martin Luther more than anything, saw God as opposed to any human agency as the only starting point of mission in its entirety (Engelsviken, 2003:481).

According to scholars such as Bosch (1991), Daugherty (2007) and Laing (2009), during the early modern period, at the 1932 Brandeburg Missionary Conference, Karl Barth was the first scholar to emphasize mission as the inherent activity of the Triune God as opposed to it being bound within the ecclesiology or soteriology frames (Bosch, 1991:389; Daugherty, 20074:163;Laing 2009:90). In fact, in the words of Youn (2018): "Barth spoke not in the usual fashion about "the mission of the church" or about "our mission" but about mission as an activity of God". This position was later substantiated by Karl Hartenstein who similar to Karl Barth taught that mission is the redemptive activity of the Trinitarian Godhead (Youn, 2018:6). This means mission belongs entirely to God, but out of his love for his people he openly invite people as participants in God's own divine mission. To put this nicely, Bosch (1991) wrote: "Mission has its origin in the heart of God. God is a fountain of sending love. This is the deepest source of mission. It is impossible to penetrate deeper still; there is mission because God loves people" (Bosch, 1991:392). The Barthian understanding of mission would only reach its peak within the next few years at the Willingen conference of the International Missionary Council in 1952. Daugherty (2007) writes: "Barth's thought became influential in the International Missionary Council and reached its peak at the 1952 Willingen Conference" (Daugherty, 2007:163)

\title{
Missio Dei at-Willingen (1952)
}

First and foremost, it is important to briefly provide a context that led to the Willingen Conference in order to identify its position as the main project among other subsequent projects. This conference came at a time when the universal church was confronted by other faiths which challenged the Christian missionary intentions. This is reflected in the conference statement which states:

\begin{abstract}
Unlike them (preceding missionary gatherings), we face a world in which other faiths of revolutionary power confront us in the full tide of victory, faiths which have won swift and sweeping triumphs, and which present to the Christian missionary movement a challenge more searching than any it has faced since the rise of Islam ${ }^{1}$
\end{abstract}

According to Matthey (2003), the Willingen conference came at the time of missiological crisis due to the catastrophic end of the missionary work in China which carried fears that a similar crisis could happen in other places in the world (Matthey, 2003:579). For decades, colonialism provided western missionary enterprises with channels into various countries. Hence, scholars like Whitworth (2012) indicated that in the past mission was mistaken to refer to Christians or persons who travelled from Western developed countries to foreign lands in order to convert the uncivilized people there. In China, where Western missionaries had settled with the similar purpose, the victory of Mao Tse-Tung, a Chinese communist revolutionary and the founding father of the People's Republic of China in 1948/1949 brought an end of favours to foreign missionaries (Goheen, 2010:67). Immediately after this communist takeover in 1949, churches and missionary agents faced expulsion and persecution never witnessed before. Missionary schools, missionary societies and missionary-run hospitals were all infiltrated by

\footnotetext{
${ }^{1}$ A Statement of the Missionary Calling of the Church: https://onlinelibrary.wiley.com/doi/epdf/10.1111/j.1758-6631.2003.tb00432.x
} 
Communist authorities (Lacy, 1955:301-302; Porter, 1992:284). As suggested by Tucker (1976), the state under communist party outwardly became antireligious and sought as a matter of priority to eliminate Christianity from the face of China by ousting all foreign mission personnel first (Tucker, 1976:115). Subsequently, Keating (2012) indicated that merely within two years of communist victory, almost all foreign Christian missionaries had left China and returned to their respective homes (Keating, 2012:60). It was in this context that the meeting of the International Missionary Council convened within the next few years.

The meeting of the International Missionary Council gathered in Willingen, Germany, in 1952 under the theme: "The Missionary Obligation of the Church". According to Philip (1999), at least about one hundred and ninety delegates coming from almost fifty countries across the world were present (Philip, 1999). It was at this conference that the idea of mission as the act of God gained more attention (Youn, 2018:7). In the words of Kemper (2014): "Missio Dei at Willingen had a strong Barthian implication of mission as the work of the Triune God-indeed, a veritable missionary God" (Kemper, 2014:189). Even though Willingen has been considered to be a milestone with regard to the concept of Missio Dei where for the first time mission was correctly placed within the doctrine of God, Sundermeir (2003) indicated that this concept was merely used in passing during the conference proceedings or discussions (Sundermeir, 2003:560). To conceptualize or put the discussions at Willingen into perspective, Bosch (2011), substantiated by Richebacher and highlighted by Gonda (2008) outlined amongst others first dominant school of thoughts that carried debates on the question of mission (Richebacher, 2003:591-592; Gonda, 2008:21).

The dominating school of though was led by the Indonesian-born missionary and Dutch Reformed Church minister, Johannes Christiaan Hoekendijk who refused to confine the definition of mission to the activities of the church and voiced a strong opposition to the churchcentric view of missions in general (Philip, 1999). As indicated by Hoedemaker (1995), Hoekendijk sought to defy traditional tendencies of incorrectly making the church to be the center of mission project, as he expressed in his pivotal question: "Can a development of mission into church really be considered a maturing? Is it not, rather, a betrayal of the fundamental missionary meaning of church" (Hoedemaker, 1995:167). Goheen (2010) writes: "Hoekendijk and others believed that the reigning ecumenical view of mission was too Christocentric and needed to be Trinitarian, and was too church-centric and needed to fin fits center in the world instead" (Goheen, 2010:71). Arguably, this was the perspective held by many from other Christian denominations during the preceding centuries (Hoedemaker, 1995:166; Richebacher 2003:591). In the words of Matthey (2003): "Missio Dei has helped to overcome the ecclesiocentric approach which had been highlighted since the 1930s" (Matthey, 2003:580). In Hoekendijk's view, it seemed as though mission had fallen into crisis simply because it was incorrectly and illegitimately solemnly placed in the hands of the church (Goheen, 2000:173). Further, Hoekendijk strongly believed that the church is merely the instrument of God's redeeming activities, which makes it a participant in God's missional work (Hoekendijk, 1964; Brouwer, 2009:57). In the words of Sundermeir (2003) "Johannes Hoekendijk merely saw the church as an appendix of God's coming into the world, the actual Missio Del" (Sundermeir, 2003:560). Philip (1999) quoted him asking emphatically saying:

To say that "the Church is the starting-point and the goal of Mission" is after all only making a phenomenological statement. It may well be that we are so wrapped up in our church-centrism that we hardly realise any longer how much our ideas are open to controversy. Would it not be a good thing to start all over again in trying to understand what it really means when we repeat, again and again, our favourite missionary text, the Gospel of the Kingdom will be proclaimed throughout the Oikoumene - and attempts to re-think our ecclesiology within this frame work of the kingdom -gospel-Apostolate-world? (Philip, 1999).

In this fashion, Hoekendijk refused to see the world as the ecclesiastical training-ground, instead, he holistically saw the world which comprised of all religions including 
Christianity, as the scene of God's great missional acts. This means God's redemptive work is not only meant for the church or Christians alone, but directed towards the whole world (Philip, 1999).

According to Philip (1999), after lively debates on the question of mission and church, the Willingen conference accepted the view that the church is merely called to be missional instruments by the Trinitarian God who called her to a full participation in his own redeeming mission. Without minimizing or downplaying the significance of missionary obligation of the church within the broader context of God's mission, to express this position the Willingen statement said:

\begin{abstract}
The Missionary movement of which we are a part has its source in the Triune God Himself. Out of the depths of His love for us, the Father has sent forth His own beloved Son to reconcile all things to Himself. That we and all men might, through the Spirit, be made one in Him with the Father in that perfect love which is the very nature of God.... We who have been chosen in Christ, reconciled to God through Him, made members of His Body, sharers in His Spirit, and heirs through hope of His Kingdom, are by these very facts committed to full participation in His redeeming mission. There is no participation in Christ without participation in His mission to the world. That by which the Church receives His existence is that by which it is also given its world-mission, As the Father hath sent me, even so I sent you (Philip, 1999).
\end{abstract}

What happened in Willingen was nothing more than a resumption of the importance of Trinitarian engagement around the world and even beyond the scope of Christianity. This conference correctly reflected the importance of the doctrine of the Trinity and made Him the starting point for all missions. In essence, this conference has again made the Triune God himself the exclusive source of all other missionary activities in the world. In the words of Matthey (2003): "Willingen's most remarkable achievement was to anchor mission in the doctrine of God or as others formulated it, to have provided a Trinitarian basis for mission" (Matthey, 2003:579), this is substantiated by Daugherty (2007) who clarifies that: "Although the term Missio Dei was not used there, the conference unambiguously connected the idea of mission with the Trinitarian nature of God" (Daugherty, 2007:163). In essence, Willingen conceptualized Missio Dei as the first order of missions which would provide a frame of reference for all other missions.

\title{
Missio Dei post-Willingen
}

Beyond the point of Willingen, the missiological challenge was on how to facilitate the transition from what was the church-centered approach of mission to the Trinitarian-Godoriented approach of mission. In the words of Scherer (1993), the challenge was: "to accomplish a successful transition from an earlier church-centered theology of mission to a kingdom-oriented one" (Scherer,1993:82). The new approach to mission as belonging to God now provided a new theological framework upon which missional paradigms were to be derived.

First the work of Lesslie Newbigin among others began the process of constructing a new approach to the understanding of Missio Dei since he had to give an account of Willingen discussions. In drafting the statement adopted by the Willingen conference, on his work entitled: "The Missionary Calling of the Church", Newbigin clearly referring to the new understand of mission being of God wrote: "The missionary movement of which we are a part has its source in the Triune God Himself". In the words of Goheen (2010), Newbigin brokered: "a compromise between competing views and in so doing formulated a theological framework which would provide the context for discussion of mission in the decades that followed" (Goheen, 2010:67,69). This statement would later provide a framework upon which mission is understood wherein mission is sourced from the Triune God. 
According to Sundermeier (2003), the concept of Missio Dei further came into use later through the publication of a book entitled Missio Dei in 1958 by the German Missiologist Georg Vicedom (Sundermeier, 2003:560). In fact, according to Konz (2018), Missio Dei as a framework encompassing human participation in the divine activity grew into popularity because of this publication (Konz, 2018:336). In his book entitled:'The mission of God: an introduction to a theology of mission', Vicedom had qualified that instead of mission being work of the church as it was traditionally believed, "mission is (in fact) the work that belongs to God" (Vicedom, 1965).

Daugherty (2007) correctly refers to the doctrine of the Trinity as the quintessentially Christian doctrine which suppresses all other doctrines (Daugherty, 2007:151). It thus follows that by association with Trinity, Missio Dei is essentially at the same level of importance when compared with other missions, since it is only through Missio Dei that God reveals his salvific activities through his Trinitarian structure, lin which there is One God, who is Father, Son, and Holy Spirit. God is thus being existing in three coequal, coeternal, consubstantial persons, namely God the Father, God the Son (Jesus Christ) and God the Holy Spirit (Paraclete) three distinct persons sharing one essence. It is very evident from the many comments of Paul for example, that the one God is in fact the Father, the Son, and the Spirit (see inter alia: Romans 15:16; 1 Corinthians 12:4-6; 2 Corinthians 13:13; Ephesians 4:2, 18-20). Tertullian spoke of the Trinity as tres personae, una substantia (three persons in one substance) (Hodgson, 1955). The Greek-speaking early Church fathers used the word ousia (being) or physis (nature). These words refer to what makes something what it is and thus the ousia of God was one being (Athanasius, n.d).

Justin Martyr was the primal user of terminology that later became the accepted Trinitarian theology. He asserts that the Son and Father are the same "being" (ousia) but nonetheless have distinct faces (prosopa). He thus anticipated the three persons (hypostases) that later emanated from Tertullian and others. Justin Martyr explains how Jesus, the Son, is distinguishable from the Father but also emanates from the Father. He made use of the analogy of a fire which represents the Son, that is lit from its source, a fiery torch which represents God the Father (Hurtado, 2005).

It is through the broader understanding of Missio Dei that other Christian missions will be properly understood. In fact, as if clarifying the position of God's mission within the context of other Christian missions, Daugherty (2007) speaks of them (other Christian missions) as mere extensions of Missio Dei (Daugherty, 2007:163). This means other Christian missions or missionary efforts, find their authenticity only as external elements of the mission of God.

\section{Missio Christos - Project A}

Missio Christos can be described as a Latin theological expression that refers to the role of Jesus Christ in fulfilling the overall purpose of Missio Dei. That being said, Missio Christos does not only point to the key role played by Jesus Christ alone, but Jesus Christ collaboratively with other members of Trinity in Missio Dei. As one of the superior project principals, Jesus Christ was flexible enough to take the human bodily form (the course of incarnation) in order to respond to the challenges of mission. Looking at project management from the perspective of construction industry, Cheng at al. (2005), opines that the executives or managers of a project must at all material times be flexible to respond to the needs and rapid challenges of a project (Cheng at al., 2005:25).

In any project, one of the important roles of project managers or principals is delegation of tasks and interpretations of specific tasks in line with the project objectives. McClinton (2015) indicated that managers of any project are always faced with an opportunity to demonstrate their innovative skills in order to deliver quality outputs within a given time (McClinton, 2015:2). Further, this is accurately observed by Turner and Muller (2003) as they write: 
The project manager should learn to delegate the planning and reporting, and most of the work. The manager's role is further to interpret the plans and progress reports, to interpret them and redefine them to achieve the project's objectives (Turner \& Muller, 2003:5).

In instances such as John 12:49, Jesus Christ outlined his authority as the only delegated person, hence he said: "The Father who sent me has himself given me a commandment about what to say and what to speak". Being the one delegated, Jesus further delegate others to participate in the mission of the Father with Him. This is demonstrated by Jesus Christ when he first prioritised calling is twelve disciples individually to become Missio Dei stakeholders through their participation and entrusted them with the responsibility of his earthly ministry. The scripture reads: "He gave them authority to drive out impure spirits and to heal every disease and sickness" (Matthew 10:1). Christ ministry is characterised by healing of diseases, driving out of impure spirits, showing/teaching kindness to others, and many other tasks that he trained his disciples on.

The process of delegation is more expressed within what Konz (2018) called the 'mandate model of mission' or the Great Commission (Matthew 28:20) as it is known. The Great Commission is where Jesus commands his followers to make disciples, baptize, and teach everything that he commanded among other nations. Having adequately demonstrated the divine work of salvation through his incarnation, suffering, death, and resurrection, Jesus Christ now gives his followers the authority and responsibility to continue the work of salvation aimed at fulfilling the goal of the Missio Dei. This means the work of salvation that Jesus Christ began during his earthly ministry, will continue until the goal of Missio Dei is fully realized. In fact, relying on the interpretation of Ephesians 1:23,Van Aarde (2015) puts it: 'The oíkovouía task of Christ and his mission from heaven will continue until the Missio Dei is fully realized in creation and through the church' (Van Aarde, 2015:50). To ensure the continuity and consistence of this mission, Jesus Christ upon his departure, informs his delegates that he is not leaving them as orphans, instead he leaves them under the guidance of the Holy Spirit which will be their helper, the Paraclete or 'Comforter', in their work to accomplish the ultimate goal of Missio Dei.

\section{Missio Spiritus - Project B}

Missio Spiritus can be described as a Latin theological expression referring to the total participation of God the Spirit in the fulfilment of the purpose of Missio Dei. Moving from the avenue of Missio Christos to Missio Spiritus, Yong (2011) declares: "Christian mission is thus always and primordially Missio Spiritus". This simply means that the mission of the Son or Missio Christos cannot be separated from the mission of the Spirit or the Missio Spiritus, hence Yong puts it that: "they are inextricably intertwined". To emphasize the inseparability of Son and Spirit, he argues that for this very reason the Spirit in Luke 3:22 came down on the Son in the early stages of his earthly ministry, in order to be with him throughout his ministry (Yong, 2011:358-360). Yong based this explanation on the argument that the אלהים רוח (ruah Elohim) God-Spirit or has been present in all divine activities, including since the creation narrative. Though, its role in the Christian doctrine of creation was only gradually recognized (Yong, 2011357).

As it is the case with Missio Christos wherein Jesus Christ plays a key role in Missio Dei, Missio Spiritus is about the Holy Spirit playing the key role in the work of achieving the goal of Missio Dei. While Missio Christos is shaped by the incarnation, suffering, death and resurrection of Jesus Christ, Missio Spiritus is initiated through the outpouring of the Spirit at Pentecost as recoded in Acts 2:1-13.

Now that it has been established that Missio Dei is at the center of all Christian missions or that mission is inherently done within the confines of Missio Dei, the work of the Holy Spirit in as far as mission project is concerned, must ultimately lead to the fulfilment of Missio Dei as it is the case with Missio Christos. This means as it is the case with Missio Christos, Missio 
Spiritus must at all material times embody the mandate of Missio Dei. In this way, Missio Dei as the main project will reflect the salvific purpose and divine action of the eternal Triune God represented equally in Missio Christos and Missio Spiritus

Schematically, Missio Spiritus becomes Project B in the context of Missio Dei, as it forms the bridge that maintains the relationship between Missio Christos, Missio Hominum and ultimately Missio Ecclesiae. In the words of Yong (2011): "The Missio Spiritus thus generates ongoing surprises that involve the crossing of borders so that agents of mission continually find the lines between insiders and outsiders being blurred" (Yong, 2011:361). This is observed by Hughes (2007) in arguing that: "The linear model of Missio Dei, Missio Christi requires us to insert Missio Spiritus and only then come to the Missio Ecclesiae". He further emphasised that the Holy Spirit must be seen as intermediation phase of all that which Christ is the mediator hence the church (ecclesiae) is only born as the climax of the Pentecost. Thus, it is through the mediatory power of the Holy Spirt that human beings are formed into a community of Missio Dei stakeholders (Hughes, 2007:431-432).

\section{Missio Hominum - Project C}

In simple terms, Missio Hominum is about the active human participation in the broader work of Missio Dei. According to Thinane (2021), the Latin theological expression Missio Hominum is about mission of relational human beings as project stakeholders due to their participation towards achieving the goal of Missio Dei (Thinane, 2021:3). While the focus in Missio Christos was Jesus Christ as the key principal, and in Missio Spiritus the key principal being the Holy Spirit, while in Missio Hominum the focus is upon human participation (as employees) in the broader work of achieving the goal of Missio Dei. However, it is important not to relegate divine agency in Missio Hominum to a secondary or passive role. In fact, the divine as the primary substance of all missions, is here embodied by all human beings or project stakeholders who participate in the work of achieving the goal of Missio Dei.

Schematically, Missio Hominum becomes Project C in the context of Missio Dei, as it is about people or individuals who are called or touched by the gospel of Christ into ultimately forming a new community of believers. Jesus Christ built Christian community by appealing to the heart of one person at a time. To put this differently, before being a community of believers, the church consisted of individuals who came together to form a uniformed fellowship of Jesus Christ. This is consistent with Hughes (2007) analysis wherein he makes use of the objective term 'us' to refer to human beings who are to be formed in a community that is seen as representing the post-resurrection body of Christ on earth (Hughes, 2007:432).

Placing all other human beings under the work of the Holy Spirit within the post-resurrection body of Christ, Hughes (2007) wrote: "The surprise is that this new body is going to include the 'unsaveable other', the gentile" (Hughes, 2007:432). This means the Holy Spirit, as the bible indicates, included all human beings or Missio Dei project stakeholders to form the body of Christ, indiscriminately included but not limited to Samaritans, the unclean, gentiles, the illegitimate, the unrighteous sinners, the prostitute, the tax collector, the eunuch and all unsaveable others. On this point, Thinane (2021) emphasised that:

God invites human beings, in particular believers, to participate in his mission; that should not suggest that he is incapable to succeed unaided, but instead through his relational and gracious nature he invites human participation because in the process they will be saved (Thinane, 2021:3).

At this point it is important to emphasize the theological logic that God first calls individuals in their individual capacity before inspiring them to join a community of believers. According to According to Genesis 12 in the Old Testament, God called Abraham in his individual capacity and promised him that nations would be blessed through him (Genesis 12:1-4). Going further, 
in Exodus 2-3, after God had heard the cries of his enslaved people, he remembered the promise he had made to Abraham, and called Moses in his individual capacity at the place of the burning bush to use him as a tool to free his people from bondage (Exodus 2: 23-25; 3: 110). In the New Testament, as it appears in Matthew 4, Mark 3, and Luke 5, Jesus Christ called Andrew and Simon (Peter) before approaching James the son of Zebedee and his brother John. Jesus called them all at the same time, but in their individual capacities (Matthew 4: 18-22; Mark 3: 16-20; Luke 5: 1-11). Using the expression Missio Hominum indiscriminately to refer to both believers and non-believers, Thinane (2021) argues that although religious communities, especially Christians, exist as a community, it is important to understand that each in their individual capacity, is called to participate in the redeeming ministry of Jesus Christ, for whom the full intention is to fulfil the goal of Missio Dei. He further points to Missio Hominum as an instrument of Missio Dei exemplified by biblical scriptures such as Matthew 14:13-21, Mark 6:30-44, John 6:1-14 and Luke 9:10-17 wherein the Triune God manifested in Jesus Christ instrumented his disciples individually to participate collectively in fulfilling the goal of Missio Dei (Thinane, 2021:3-4).

As if getting any closer to the idea of Missio Hominum, a similar approach is used by Wiguna (2020), who spoke of Missio Pauli (Mission of Paul) and argued that the Apostle Paul is a model of a person who has excellent participation to Missio Dei (Winguna, 2020:71). Arguably, a concern in using Paul as a model for achieving the goal of the Missio Dei is that Paul, like all other believers, merely sought perfection and therefore his imperfect life cannot be singled out to dictate a model of the Missio Dei. His contributions to world Christianity are sufficient to be quoted among many other apostles who laid the foundation for Christianity. Hence, his life and teachings can generally be used to flow into Missio Hominum as a model that focuses on human participation in general.

Missio Hominum is thus about relational individuals who will ultimately be drawn into a new community of believers (Missio Ecclesiae).To include Missio Hominum within the framework of Missio Dei, one can extend the Missio Dei premise to say: Missio Dei is about God the Father sending God the Son to the world, and God the Father and the Son sending God the Spirit to the world, and the Father, Son and Spirit working through people who will form a new community that the Father, Son and Spirit will send into the world.

\section{Missio Ecclesiae - Project D}

Missio Ecclesiae is a Latin theological expression referring to the mission of the church in relation to the total fulfilment of the goal of Missio Dei. Wiguna (2020) precisely suggests that Paul, particularly regarding the Church at Ephesus, exhorted believers to pray for the whole world, including kings, to fulfil Missio Dei's goal of total salvation for all humanity (Wiguna, 2020:56,60-66). Schematically, Missio Ecclesiae becomes Project D in the context of Missio $D e i$, as it is about a community called to proclaiming the gospel of salvation through Jesus Christ. Missio Ecclesiae is about the participation of a community that consist of followers of Christ (Christians) as stakeholders within Missio Dei assembled under the mandate of fulfilling or accomplishing its eternal goal. In essence, this new community becomes a lighthouse that is used to point people of the world to the eternal goal of Missio Dei. This new community, this body of Christ or the new fellowship of the Spirit reminds of the chosen people of Israel through whom God wanted to redeem the world; the new community receives the gift of the Spirit from Jesus Christ and in turn uses it to redeem the world. According to Yong (2011), this community is the newly reconstituted people of God who are empowered through the touch of the Spirit (Yong 2011:360). This spirit is the same spirit that empowered God the Son at the beginning of his earthly ministry, the same spirit that filled the Lord's disciples, and the same spirit is now descending upon this new community and enabling or using it to accomplish the goal of Missio Dei. This community act collectively in the work of achieving the goal of Missio Dei while at the same time it exists to represent or give the foretaste of the kingdom of God. In the words 
of Laing (2009): "The very existence of the Church springs from God's sending forth of His son" (Laing, 2009:91).

The term koIvwvía - Koinonia (call to fellowship) can be translated to mean community, common life, fellowship, communion etc. These terms are meant to signify a group of people who exist within a common religious faith or who practice/observe the same religious rites. The primary objective of Missio Dei is salvation of all humans, and once such salvation prevails, then the kingdom of God will be the order of the day. The end goal of Missio Dei is the redemption of the whole world and not only the church (Arthur, 2015:1). Klaasen (2020) indicated that for Paul, the term Koinonia should be used along with ठıakovía diakonia (call to service) to refer to this new community of God since the term diakonia unites Christian communities of Corinth, Jerusalem, Macedonia, and others. He then writes: "They share in the continuous mission of Jesus Christ. This mission is reflected in practical service of providing for the physical needs of the new communities" (Klaasen, 2020:127).

The church as a unique community, exist merely to symbolize or represent the foretaste of the kingdom of God which will only come once the goal of Missio Dei is fully achieved in the world. It is in this foretaste of God's kingdom where the eternal Lordship of God the Father, God the Son and God the Holy Spirit is experienced as the model of the future intended Kingdom of God. Bosch (1991) explained the involvement or participation of the church in the divine mission (Missio Del) saying: "Father, Son, and Holy Spirit sending the church into the world" (Bosch 1991:390). While at the same time Thinane (2021) puts it:

\begin{abstract}
The resurrection of Jesus from the dead brought the age of the church, when his disciples became fully inspired and authorised to carry on the mission of Jesus in the community. Thus, the resurrection was an event when Christ was transferring authority to the church in order for it to work as his agent (Thinane, 2021:3)
\end{abstract}

Hughes (2007) described the work of the Holy Spirit upon Christ's community by arguing that: "From the very beginning the Spirit rests on the new community, creating its koinonia as the sacramental reality that is the body of the risen Christ". (Hughes, 2007:432). Pointing to Baker (1986), Bosch (2011) reunited the church with the total human community by arguing that:

The church exists only as an organic and integral part of the human community. As soon as it tries to view its own life as meaningful in independence from the total human community it betrays the major purpose of its existence (Baker, 1986:159), (Bosch, 2011:397).

\title{
Mission collaboration for Missio Dei
}

This paper believes that using the project management model to demonstrate the coordination and collaboration of missions in the context of Missio Dei inherently leads to an adequate understanding of each role that each mission is or should play, in achieving the objective of Missio Dei. Missio Christos, Missio Spiritus, Missio Hominum and Missio Ecclesiae, do not exist to compete with one another as if they were autonomous entities, but are there to work together to achieve the overall goal of Missio Dei. In light of the project management model as used in this paper, each mission has been calculated to show or demonstrate the role they play in achieving the goal of Missio Dei. Missio Dei, as the main project led by God the Father, the Son and the Spirit, comprises a network of projects that performs the participatory factions aimed at the fulfilment of the main objective of the main project.

Accordingly, Missio Dei is identified as the main project involving the work of God the Father, the Son and the Spirit as project managers. Secondly, Missio Christos as project A focusing on the key role played by Jesus Christ in establishing a community that will participate in achieving the goal of Missio Dei. Thirdly, Missio Spiritus as project B forms the bridge that maintains the relationship between Missio Christos, Missio Hominum and ultimately Missio 
Ecclesiae. Fourthly, Missio Hominum as project $\mathrm{C}$ in the context of Missio Dei, comprising of people or relational individuals who are each called into ultimately forming a new community of believers that will collectively participate in achieving the goal of Missio Dei. Lastly, Missio Ecclesiae as project $\mathrm{D}$ as it is about a unique community or the church in particular called to proclaiming the gospel of salvation through Jesus Christ.

For the sake of completeness and clarity, a diagram showing the relation between Missio Dei and other missions is provided below:

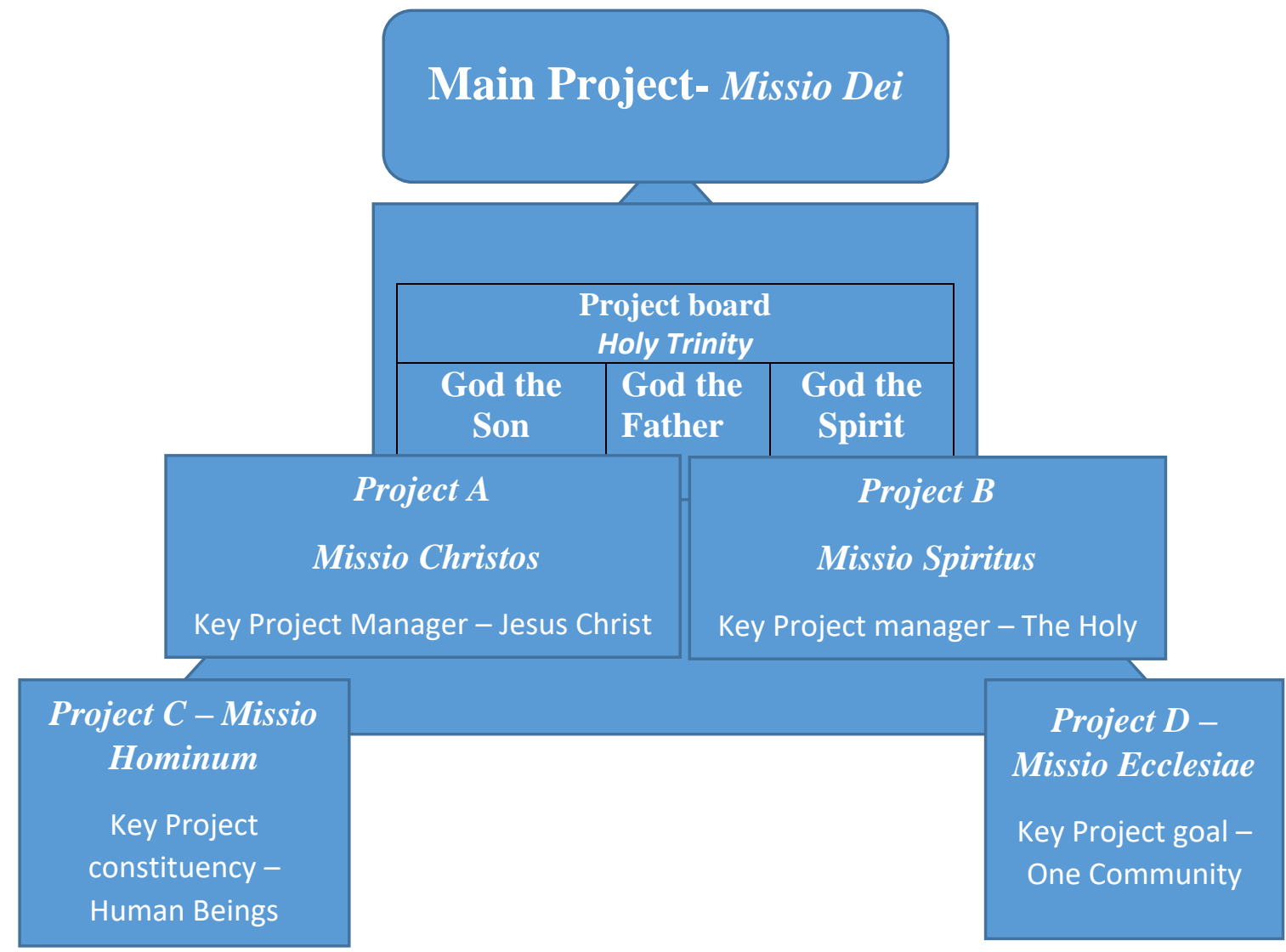

\section{Conclusion}

In this paper a proposal was presented which attempts to use a project management model to unite Christian missions under the missiological paradigm of Missio Dei. First, the concept of project management and its application was presented. Second, the background or the development of Missio Dei as a missiological paradigm was discussed and the current findings were further outlined. Third, it focused on a network of Christian missions such as Missio Christos as Project A, Missio Spiritus as Project B, Missio Hominum as Project C and Missio Ecclesiae as Project D, which are sub-projects designed to help achieve the goal of Missio Dei. Consequently, the most important conclusion that can be drawn from this work is therefore that project management models can be used within the field of missiology to help bring a more profound understanding of Missio Dei as the main project in relation to the role of other Christian missions such as Missio Christos, Missio Spiritus, Missio Hominum and Missio Ecclesiae in the project of fulfilling the eternal goal of Missio Dei. 


\section{Reference List}

Antlova, K. (2014). Agile Approach in the Project Management of the Czech Companies. Procedia Technology, 16, 929-933.

Arthur, E. (2015). Missio Dei and the Mission of the Church. [Available online at: https://static1.squarespace.com/static/56dee43ee321400514f98522/t/575c31a8e32140042b b2b7bb/1465659816891/3+MISS+301+Mag+3.pdf].

Athanasius, (n.d). Defence of the Nicene Definition 22 (165), in The Nicene and Post Nicene Fathers, 4, ed. P. Schaff and H. Wace, New York, NY: The Christian Literature Company, 1892.

Baars, W., Harmsen, H., Kramer, R., Sesink, L. \& Van Zundert, J. (2006). Project Management Handbook Version 1.1 -July 2006 DANS -Data Archiving and Networked Services The Hague -2006. [Available online at: https://www.projectmanagement-training.net/wordpress/wpcontent/uploads/2015/11/book_project_management.pdf].

Baker, J. (1986). A Summary and Synthesis, in Limouris, 152-162

Buys, P.J. (2020). The roots of Missio Dei in the Reformation, and its implications for theological education. In die Skriflig / In Luce Verbi, 54(2).

Cheng, M.-I., Dainty, A.R.J. \& Moore, D.R. (2005). What makes a good project manager? Human Resource Management Journal, 15(1), 25-37.

Chin, C., Spowage, A. \& Yap, E. (2012). Project Management Methodologies: A Comparative Analysis. Journal for the Advancement of Performance Information and Value, [online] 4(1), 106-106. [Available online at: http://journal.cibw117.org/index.php/japiv/article/view/102].

Cleland, D.I. \& Kerzner H. (1985). A project management dictionary of terms. New York: Van Nostrand Reinhold.

Daugherty, K. (2007). Missio Dei: The Trinity and Christian Missions. Evangelical Review of Theology, 31(2), 151-168. [Available online at at: https://eds.b.ebscohost.com/eds/detail/detail?vid=0\&sid=e7297d35-1baf-44ca-9a66-

715d2ba7342d\%40sessionmgr101\&bdata=JnNpdGU9ZWRzLWxpdmUmc2NvcGU9c2I0ZQ $\% 3 d \% 3 d]$ [Accessed 19 Oct. 2021].

Engelsviken, T. (2003). MISSIO DEI: THE UNDERSTANDING AND MISUNDERSTANDING OF A THEOLOGICAL CONCEPT IN EUROPEAN CHURCHES AND MISSIOLOGY. International Review of Mission, 92(367), 481-497.

Goheen, M.W. (2000). As the Father has sent me, I am sending you': J.E. Lesslie Newbigin's missionary ecclesiology'. [online] localhost. [Available online at: https://dspace.library.uu.nl/handle/1874/597] [Accessed 16 Oct. 2021].

Goheen, M.W. (2010). Historical Perspectives on the Missional Church Movement: Probing Lesslie Newbigin's Formative Influence. Trinity Journal for Theology and Ministry, 4(2), 62 84.

Gonda, L. (2008). The Service of Evangelism, the Evangelism of Service : The Influence of John R. Mott, Hendrik Kraemer, Willem A. Visser 't Hooft and Johannes C. Hoekendijk on the Development of the Understanding of Mission in the Reformed Church in Hungary (19101968). [online] localhost. [Available at: https://dspace.library.uu.nl/handle/1874/31908] [Accessed 18 Sep. 2021]. 
Hodgson, L. (1955). The Doctrine of The Trinity. [online] Amazon. C. Scribner's sons. Available at: https://www.amazon.co.uk/Doctrine-Trinity-L-Hodgson/dp/B0007HZNIK [Accessed 5 Nov. 2021].

Hoedemaker, B. (1995). The Legacy of J. C. Hoekendijk. International Bulletin of Missionary Research, [online] 19(4), 166-170. Available at: http://www.internationalbulletin.org/issues/1995-04/1995-04-166-hoedemaker.pdf.

Hoedemaker, B. (1995). The Legacy of J. C. Hoekendijk. International Bulletin of Missionary Research, 19(4), 166-170.

Hoekendijk, J.C. (1964). De kerk binnenste buiten [The church inside out], Ten Have, Amsterdam

Huda, M.N. (2016). Definition of Project Management: What Is Project. www.academia.edu. [online] [Available online at: https://www.academia.edu/31616426/Definition_of_Project_Management_What_Is_Project]

Hughes, R.D. (2007). After the Empire: Mission in the Power of the - ProQuest. [online] [Available online at: https://www.proquest.com/docview/214713979?pqorigsite $=$ gscholar\&fromopenview $=$ true] [Accessed 14 Sep. 2021].

Hurtado, L (2005). Lord Jesus Christ: Devotion to Jesus in Earliest Christianity: Hurtado, Larry W.: 9780802831675: Amazon.com: Books. [online] Available at: https://www.amazon.com/Lord-Jesus-Christ-Devotion-Christianity/dp/0802831672 [Accessed 5 Nov. 2021].

Hurtado, L. (2005). Lord Jesus Christ: Devotion to Jesus in Earliest Christianity, Eerdmans.

Karaman, E. \& Kurt, M. (2015). Comparison of project management methodologies: prince 2 versus PMBOK for it projects. [Available online at: https://www.semanticscholar.org/paper/Comparison-of-project-managementmethodologies\%3A-2-Karaman-Kurt/8cb0ba8f62b15339f20926e9df31623a21b8e06c].

Keating, J.C.W. (2012). A Protestant Church in Communist China: Moore Memorial Church Shanghai, 1949-1989. [online] Google Books. Lexington Books. Available at: https://books.google.co.za/books?hl=en\&lr=\&id=DHNS9nFE10IC\&oi=fnd\&pg=PR5\&dq=chur ch+mission+suspended+after+1949+communist+takeover\&ots=uGkElsbBn5\&sig=1 bvRkcQ $4 n N C B M m B G z x 9 O u J e B E m 4 \&$ redir_esc=y\#v=onepage\&q\&f=false [Accessed 4 Nov. 2021].

Kemper, T. (2014). The Missio Dei in Contemporary Context. International Bulletin of Missionary Research, 38(4), 188-190.

Klaasen, J. (2020). Diakonia and Diaconal Church. Missionalia, 48(1).

Konz, D.J. (2018). The even Greater Commission: Relating the Great Commission to the Missio Dei, and human agency to divine activity, in mission. Missiology: An International Review, 46(4), 333-349.

Koskela, L. \& Howell, G. (2002). THE THEORY OF PROJECT MANAGEMENT: EXPLANATION TO NOVEL METHODS. [online] Available at: https://iglcstorage.blob.core.windows.net/papers/attachment-8ef324db-750a-40c3-9c17273db32b54e2.pdf.

Lacy, C. (1955). The Missionary Exodus from China. Pacific Affairs, 28(4), 301-314.

Laing, M. (2009). Missio Dei: Some Implications for the Church. Missiology: An International Review, 37(1), 89-99. 
Matthey, J. (2003). GOD'S MISSION TODAY: SUMMARY AND CONCLUSIONS. International Review of Mission, 92(367), 579-587.

McClinton, P. (2015). Project Management Methodologies: A Review of the Literature. www.academia.edu. [Available online at: https://www.academia.edu/7055300/Project_Management_Methodologies_A_Review_of_th e_Literature] [Accessed 17 Mar. 2020].

Philip, T.V. (1999). Edinburgh to Salvador: twentieth century ecumenical missiology: a historical study of the ecumenical discussions on mission. Delhi: Ispck. [Available online at https://www.religion-online.org/book-chapter/chapter-2-church-and-mission/] [Accessed 16 Oct. 2021].

Pierson, P. (eds.), (1993). The Good News of the Kingdom. Mission Theology for the Third Millennium. Maryknoll, N.Y., 82-88.

PMI - Project Management Institute (2017). A guide to the Project Management Body of Knowledge : (PMBOK® guide). 6th ed. Newtown Square, Pennsylvania, USA: Project Management Institute.

Porter, A.N. (1992). War, colonialism and the British experience: the redefinition of Christian missionary policy, 1938-1952. Kirchliche Zeitgeschichte, [online] 5(2), 269-288. [Available https://www.jstor.org/stable/pdf/43099816.pdf?casa_token=q7hcRjW1gC0AAAAA:HsHtnP _ R1VaDoO51wbA8Mz-XDxdqxDbCMvwgDjumfjy0-

1CwVUJG6YLahRK2svK44PL2yxSvmrF4IdIPVXsORyKZbyZ3bwW-

HJunL3_MlvjZ8v0BCoNqog] [Accessed 16 Oct. 2021].

Richebächer, W. (2003). Missio Dei: The basis of mission theology or a wrong path? International Review of Mission, 92(367), 588-605.

Scherer, J.A. (1993) "Church, Kingdom, and Missio Dei: Lutheran and Orthodox Correctives to Recent Ecumenical Mission Theology", in Van Engen, Charles, Gilliland, Dean S. and

Schirrmacher, T.(2017), 'Missio Dei: God's missional nature, theological commission of the world evangelical alliance', transl. R. McClary, in T.K. Johnson (ed.), World of theology series, vol. 10, 1-83, Verlag für Kultur und Wissenschaft, Bonn.

Soares, D., Lotter, G. \& Van Der Merwe, S. (2017). [Available online at: http://www.scielo.org.za/pdf/ids/v51n1/01.pdf [Accessed 17 Sep. 2021].

Statement on the missionary calling of the church. (2003). International Review of Mission, 92(367), 606-616. [Available online at https://onlinelibrary.wiley.com/doi/epdf/10.1111/j.17586631.2003.tb00432.x] [Accessed 16 Oct. 2021].

Suess, P. (2003). MISSIO DEI AND THE PROJECT OF JESUS: THE POOR AND THE "OTHER" AS MEDIATORS OF THE KINGDOM OF GOD AND PROTAGONISTS OF THE CHURCHES. International Review of Mission, 92(367), 550-559.

Sundermeier, T. (2003). MISSIO DEI TODAY: ON THE IDENTITY OF CHRISTIAN MISSION. International Review of Mission, 92(367), 560-578.

Thinane, J.S. (2021). Missio Hominum as the compassionate response to socio-economic and vaccine challenges during COVID-19 in South Africa. HTS Teologiese Studies / Theological Studies, 77(3).

Tucker, N.B. (1976). An Unlikely Peace: American Missionaries and the Chinese Communists, 1948-1950. Pacific Historical Review, [online] 45(1), 97-116. Available at: https://www.jstor.org/stable/pdf/3637302.pdf?casa_token=W2PfN3XiyisAAAAA:5RjlkIKgLbE yDDIpML8as6qWzhwjWoK7ZNiS3elXVWcHCOyqh4t6V8- 
DHqtcHJgTdKyNwQsEYKPEuirRC1s4nHsXy6UiNhE4xWynxJjCZ6SVVcnmsm_gHQ [Accessed 4 Nov. 2021].

Turner, J. Rodney., \& Müller, R. (2003). On the nature of the project as a temporary organization. International Journal of Project Management, 21(1), 1-8. https://doi.org/10.1016/s0263-7863(02)00020-0

Van Aarde, T.A. (2015). The use of oíkovopía for the missional plan and purpose of God in Ephesians 1:3-14. Missionalia, 43(1).

Van der Merwe, I.W. (2017). (PDF) How relevant are waterfall project management methodologies in today's modern project environment? [Available online at: https://www.researchgate.net/publication/321808034_How_relevant_are_waterfall_project_ management_methodologies_in_today].

Vicedom, G.F. (1965). The mission of God: an introduction to a theology of mission. St. Louis: Concordia.

Wells, H. (2012). How Effective Are Project Management Methodologies? An Explorative Evaluation of Their Benefits in Practice. Project Management Journal, 43(6), 43-58.

Whitworth, D.M. (2019). Missio Dei and the means of grace: a theology of participation. Eugene, Oregon: Pickwick Publications.

Wiguna, P. (2020). Christians' Prayer, Missio Dei, and Missio Ecclesiae: An Exegetical Study $\begin{array}{llll}\text { of } 1 \text { Timothy [Available } & \text { [online] }\end{array}$ https://122.200.2.51/index.php/DIL/article/viewFile/2221/815] [Accessed 23 Oct. 2021].

Youn, C.-H. (2018). Missio Dei Trinitatis and Missio Ecclesiae : A Public Theological Perspective. International Review of Mission, 107(1), 225-239. 